\title{
Edward Swanson
}

The Complete Guide to Acquisitions Management. By Frances C. Wilkinson and Linda K. Lewis. Westport, Conn.: Libraries Unlimited, 2003. 312p. \$45 softbound (ISBN 156308-892-4); \$60 hardbound (ISBN 1-56308-890-9).

Ross Atkinson writes, "The place and image of the library in the institution is mirrored in the position and perception of the acquisitions operation in the academic library." Acquiring and managing access to information resources remains a core function within all types of libraries. However, the library acquisition function has changed during the past decade. The exponential growth of electronic resources combined with budgetary constraints and rising information costs have resulted in many challenges for libraries. It is important that librarians and support staff responsible for library acquisitions have the skills and knowledge necessary to successfully manage the acquisition and delivery of information resources.

The Complete Guide to Acquisitions Management was written to fill a gap in library education. The authors conducted a survey of American Library Association-accredited graduate library programs in 1999 and summarized the outcomes in the introduction. Results of the survey (64 percent response rate) indicated that only 13.9 percent of graduate library programs teach a separate course on acquisitions management, but 93.5 percent do include it as a component in other courses. The majority of respondents (79.3 percent) supported the publication of a new textbook on acquisitions management. The authors' goal was to publish an up-to-date resource to support training of staff new to library acquisitions and "provide the reader with both procedural and philosophical approaches to acquisitions"(xi).

Authors Wilkinson and Lewis are well qualified to write a book on acquisitions management based on their own relevant job experience at the University of New Mexico and numerous publications on library acquisition related topics. The authors effectively synthesize information gathered from numerous resources into a wellorganized volume that succinctly covers a broad range of topics. However, this book does not provide the same level of detail and discussion that appeared in the highly regarded second edition of Understanding the Business of Library Acquisitions, edited by Karen Schmidt. ${ }^{2}$ What the book does offer is a good introduction to acquisitions management, educating the reader on core acquisition functions. References and links throughout the book lead the reader to resources that will most often provide more in-depth discussion of topics.
The book is organized into twelve chapters that address the following topics: organization of acquisition departments; acquisitions systems; publishing industry; vendor selection and evaluation; acquiring books and media; serials; electronic resources; out-of-print and antiquarian materials; gifts and exchange programs; bindery operations; outsourcing acquisitions; and professional ethics. An appendix follows that includes useful references and links to automated acquisitions systems, relevant conferences, publisher and vendor sites, electronic discussion lists and Web sites, acquisitions-related journals, organizations, and reference tools. A glossary of more than two hundred terms (some with links to additional resources) is included. An index to the book's content completes the volume.

Chapters 4 through 9 offer the most immediate value to staff new to library acquisitions. Chapter 4 provides excellent discussions on vendor types, vendor selection criteria, the basics of the request for proposal (RFP) process, and vendor evaluation criteria; the RFP discussion is especially useful for anyone not experienced with that process. Chapters 5 through 9 address the specifics of acquiring different formats (such as books) and the management of gifts and exchange programs. Of particular interest is chapter 7, "Acquiring Electronic Resources." During the past decade, electronic resources have increased in both number and acceptance by library users. A particular challenge for libraries has been how to effectively integrate management of electronic resources into existing organizational structures. Chapter 7 provides the reader with a good introductory treatment of electronic resource management. New developments in the area of electronic resource management since publication of this book, such as the Digital Library Federation Electronic Resource Management Initiative, will require the reader to supplement their knowledge with more current information. However, if the reader refers to the appendix or glossary, there are references and links to useful resources (for example, the entry under Digital Library Federation in the glossary includes a link to the federation's Web site).

Chapter 11, "Outsourcing Acquisitions," provides a balanced discussion of when to outsource, what to outsource, and the advantages and disadvantages of outsourcing. As the authors point out, "Outsourcing should be a management tool, not a goal" (216). Chapter 12, "Professional Ethics," provides a good introduction to the issues, especially ethics in acquisitions. This is a topic that is often inadequately addressed in similar texts. The appendix and glossary add 
value to the book by providing the reader with access to a wide range of useful resources.

The Complete Guide to Acquisitions Management does achieve the authors' goal of providing an up-to-date, comprehensive guide to acquisitions management for staff new to the field. Published in 2003, the content remains timely. As previously noted, the book does not provide the detailed level of discussion that more experienced acquisitions and electronic resource librarians require that appeared in Understanding the Business of Library Acquisitions. However, this book does provide a good introduction to acquisitions management and is recommended for graduate library school collections and library technical service or acquisitions department reference collections.-Robert Alan(roal@psulias.psu.edu), Pennsylvania State University, University Park

\section{References}

1. Ross Atkinson, "The Acquisitions Librarian As Change Agent in the Transition to the Electronic Library," Library Resources \& Technical Services 36, no. 1 (Jan. 1992): 7.

2. Karen Schmidt, ed., Understanding the Business of Library Acquisitions, 2nd ed. (Chicago: ALA, 1999).

Managing Information Technology: A Handbook for Systems Librarians. By Patricia Ingersoll and John Culshaw. Westport, Conn.: Libraries Unlimited, 2004. 199p. \$45 hardbound (ISBN 0-313-32476-X).

This handbook is a much-needed text regarding systems librarianship and covers topics not encompassed by or in need of updating from earlier works by Thomas C. Wilson and Rachel Singer Gordon. ${ }^{1}$ Many systems librarians today are still self-taught, despite the widening of library school curricula to include more information technology basics, and this handbook is a must for the desks of those librarians. Although the Wilson text contains a more thorough (though rapidly becoming dated) treatment of the history of computers in libraries and the philosophy of systems librarianship, Ingersoll and Culshaw provide more than adequate introductory material and address a wide assortment of subject areas relating to information technology. Including many practical tools and lots of tips and advice, their work amounts to a compilation of the many and sundry things they have learned and developed during their collective thirty years of on-the-job learning in an academic library setting.

The first chapter of the work is devoted to planning. With technology playing the major role it does in today's libraries, the importance of the systems librarian's involvement from the outset in any planning process is stressed. The authors appropriately emphasize that successful results are particularly dependent on systems staff involvement in any planning related to integrated library system (ILS) migration. With the flux in the technology marketplace and the accompanying demise of so many ILS vendors and systems, system migration has become a high priority for many systems departments, and those not affected now can expect to have to deal with the problem somewhere down the road. Ingersoll and Culshaw therefore are right to consider the planning for migration as a subject to be handled in some detail, as they do.

The authors emphasize that reporting lines and staffing should respond in a dynamic way to environmental changes. They note that close alliances between the library and the computer center are likely on today's college and university campuses; if a formal reporting connection does not exist between the library and the computer center, one can generally expect that there is a strong informal relationship, and they stress communication with the intent of shifting "the emphasis from control of information to sharing it" (39). Good advice.

A systems librarian must be an excellent communicator within his or her own organization and also in interacting with peers outside their library as well as with others who may not be so knowledgeable about the ins and outs of technology. Ingersoll and Culshaw stress that the use of technical jargon and acronyms can often inhibit communication with those outside the systems department, in much the same way as the use of library jargon and acronyms can sometimes inhibit communication between librarians and nonlibrarians.

The wide variety of topics covered in the work is both a strength and a weakness. On the plus side, this work will surely open the eyes of some students and even some systems librarians to the ever-expanding role that they are being asked to play. On the other hand, some of the important topics covered, such as statistical reporting, link checking, wireless computing, and other service-related topics, are covered in a summary style, taking up only a few pages. The reader will often wish that these and a number of other topics were covered in more detail.

For a book published in 2004, the dates of the literature cited seem a bit problematic. The authors quote abundantly from literature published in the mid-1990s or even earlier. Given the subject nature of the work and the fluid nature of the systems field, the reader is often left wondering about the relative absence of systems librarianship literature from 2000 and beyond. Although such literature is not plentiful, it is always difficult for the skeptical reader to give credence to the continuing validity of materials more than ten years old in this rapidly changing field. The authors might have found it fruitful and useful to their readers to do a better job of explaining the relevance of the materials cited, even if only as an attempt to provide a historical perspective.

At 132 pages, with an additional 49 pages devoted to resource materials containing a sample local area network 